\title{
E-Service Delivery: A Comparative Study of SETU, Maha e-Seva Kendra and MahaOnline
}

\author{
Prajakta Warale $^{1}$ and Hemlatha Diwakar ${ }^{2}$ \\ ${ }^{1}$ Associate Professor, Rajgad Institute of Management Research \& Development, Pune, M.H., India. \\ ${ }^{2}$ Ex-state Bank of India IT Chair Professor, National Institute of Bank Management, Pune, M.H., \\ India.
}

CITATION: Warale, Prajakta and Diwakar, Hemlatha (2019), "E-Service Delivery: A Comparative Study of SETU, Maha e-Seva Kendra and MahaOnline", MERC Global's International Journal of Management, Vol. 7, Issue 3, pp. 238-246.

ARTICLE HISTORY: Submitted: March 10, 2019, Revision received: April 22, 2019, Accepted: April 30, 2019

ARTICLE TYPE: Review paper

\begin{abstract}
e-Governance involves the use of Information and Communications Technology (ICT) at the front end, back-end, service design, and deployment. Advancement in ICT has proved faster, reliable service delivery at the doorstep of citizens. This paper presents a comparative analysis of e-Service delivery initiative SETU, Maha e-Seva Kendra (CSC) and MahaOnline with special reference to Maharashtra (India). Finally, the paper presents a review of some noteworthy literature on e-service delivery progress across the world.
\end{abstract}

KEYWORDS: e-Services, e-Participation, e-Governance Index, Mahaonline, Digital India.

\section{BIBLIOGRAPHY}

1. Agarwal, Rajesh; Singh, Viredra and Pandey, Nikhil (2013), "Case studies of e-Governance in India, SCA Performance Assessment \& CSC Survey in Maharashtra", International Journal of Management, Vol. II, pp. 123-145.

2. Jonathan, Oluranti; Ayo, Charles and Misra, Sanjay (2015), "A comparative study of e-Government successful implementation between Nigeria and Republic of Korea", Asia-Pacific World Congress on Computer Science and Engineering, pp. 301-132.

3. Kalsi, Nirmaljeet Singh; Kiran, Ravi and Vaidhya, S. C. (2008), "ICT and Good Governance: A Study of Indian Environment", E-Governance in Practice, pp. 1-25.

4. Rao, T. P. Rama; Rao, V. Venkata; Bhatnagar, S. C. and Satyanarayana, J. (2004), E-Governance Assessment Frameworks (EAF Version 2.0) for GOI Dept. of IT, pp. 110-135.

5. Sah, Vanishree (2018), "Comparative Study of Service Quality of Uber and Ola", MERC Global's International Journal of Management, Vol. 6, Issue 3, pp. 82-87.

6. UN e-Government survey (2018), United Nations Department of Economic and Social Affairs (UNSEDA).

7. Warale, Prajakta N. and Diwakar, Hemalatha (2015a), "A Study of Citizen Satisfaction for e-Governance Initiative SETU in Maharashtra (INDIA)", International Journal of Computer Applications, Vol. 124, Issue 17, pp. 12-19.

8. Warale, Prajakta N. and Diwakar, Hemalatha (2015b), "A Study on The Relationship Between Service Quality And Citizen Satisfaction For Setu, An E-Governance Initiative, In Maharashtra", India Asia Pacific Journal of Research, Vol. 1, Issue XXIX, pp. 78-88.

9. Warale, Prajakta N. and Diwakar, Hemalatha (2019), "Sustainable Maturity Model for e-Governance: An Indian Scenario", Research Review International Journal of Multidisciplinary, Vol. 4, Issue-01, pp. 761744. 